\title{
ARCHITEKTURA I DOSTEPNOŚĆ OBIEKTÓW UŻYTECZNOŚCI PUBLICZNEJ DLA OSÓB Z DYSFUNKCJĄ WZROKU
}

\begin{abstract}
Istnieje potrzeba wygenerowania wspólnych i spójnych zasad, które pozwoliłyby zrozumieć niepełnosprawność jako zjawisko systemowe. Istnieje wiele różnych definicji niepełnosprawności. Skutki, jakie pociąga za sobą dysfunkcja wzroku zależą od kilku czynników. Przestrzeń wielosensoryczną łączy w sobie elementy architektury, sztuki i komunikacji medialnej. Istotą projektu architektonicznego obiektów użyteczności publicznej jest funkcjonalność, prostota i intuicyjność w użytkowaniu. Duży nacisk jest przykładany do projektowanie przestrzeni i przedmiotów w taki sposób, aby ich funkcja była zrozumiała dla każdego użytkownika, bez względu na jego doświadczenie czy zaawansowany stopień dysfunkcji.
\end{abstract}

Słowa kluczowe: architektura, projektowanie, obiekty rehabilitacji, osoby $\mathrm{z}$ dysfunkcją wzroku

\section{Jakość życia osób z niepełnosprawnością wzroku}

Jakość życia osób z niepełnosprawnością wzroku, w ostatnich latach, stała się przedmiotem badań w wielu dziedzinach. Szczegółowo analizowane są zjawiska niepełnosprawności i rodzaje barier budowlanych, które utrudniają nieskrępowaną kontrolę nad funkcjami osób dysfunkcyjnych. Istnieje potrzeba stworzenia wspólnych i spójnych zasad, które pozwolą zrozumieć niepełnosprawność jako zjawisko systemowe. Zwolennicy podejścia systemowego twierdzą, że niepełnosprawność wzroku jest relatywna i jest wynikiem ludzkiej podatności na choroby i cechy środowiska, które powodują zaostrzenie ujawniania się ograniczonych zdolności sensorycznych i poznawczych.

Istnieje kilka różnych definicji niepełnosprawności wzroku. Środowisko medyczne w zakresie postrzegania problemów tej niepełnosprawności odnosi się do osób dotkniętych chorobą. Osoba z niepełnosprawnością wzrokową jest zdiagnozowana jako osoba chora. Popularyzacja zjawiska stygmatyzacji środowiska niepełnosprawnych prowadzi do przyjęcia, że ograniczona wydajność jest następ-

\footnotetext{
${ }^{1}$ Adam Rybka, Politechnika Rzeszowska, Zakład Urbanistyki i Architektury, al. Powstańców Warszawy 12, 35-959 Rzeszów; tel. 178651624; akbyr@prz.edu.pl
} 
stwem wad, braków i błędów. Obecnie redefiniuje się rolę osoby niepełnosprawnej. Taka osoba ma równe prawo do korzystania ze środowiska zbudowanego. Akcenty są zmieniane w celu uwzględnienia stanu badań ludzkich cech poznawczych.

Światowa Organizacja Zdrowia przyjęła w 2001 roku nowy system modelu niepełnosprawności. Niepełnosprawność jest rozumiana jako wynik złożonych relacji między stanem zdrowia jednostki i określonej grupy ludzi oraz czynnikami zewnętrznymi, które reprezentują warunki, w których poszczególne osoby funkcjonują. Poszerzona definicja traktuje każdą osobę z niepełnosprawnością i sytuację w jakiej się ona znajduje jako indywidualną i jedyną w swoim rodzaju.

\section{Dysfunkcja wizualna}

Zaburzenia wzrokowe zależą od wielu czynników. Ważny jest wiek, w którym dochodzi do ograniczenia lub utraty wzroku. Istnieje jakościowa różnica między osobami niewidomymi od urodzenia lub wczesnego dzieciństwa a niewidomymi, którzy utracili wzrok powyżej wieku 5 lat. Tych ostatnich bardziej doświadcza ich niepełnosprawność i jest to uzależnione od charakteru utraty wzroku, zakresu utraty wzroku (całkowita utrata widzenia, zdolność do poczucia światła i z różnym stopniem widzenia); osobowości, styl życia, zainteresowań.

W przypadku dysfunkcji wzroku występującej od urodzenia lub powstałego we wczesnym dzieciństwie, niepełnosprawność może polegać na opóźnieniu rozwoju procesów funkcji poznawczych dziecka, opóźnieniu rozwoju mowy, zdolności percepcji otoczenia, socjalizacji oraz orientacji w przestrzeni. Osoby cierpiące z powodu utraty wzroku mają problemy z rozwojem pełnej osobowości (suma cech psychologicznych, takich jak przekonania, postawy, temperament, zdolności, charakter - specyficznych dla jednostki i określających konkretne zachowania i reakcje na te same zjawiska i sytuacje). Zwłaszcza osoby z nagłą utratą wzroku cierpią na depresję. Utrata wzroku powoduje "zdezorganizowaną" osobowość, wynikającą z utraty pełnej wartości fizycznej człowieka. W wyniku gwałtownej lub postępującej dysfunkcji wzroku pojawia się utrata mobilności, która powoduje przywiązanie osoby do jednego miejsca, w wyniku strachu i poczucie zależności od innych osób. Utratę możliwości korzystania z narzędzi codziennego życia określają progresywne zaburzenia osobowości, brak akceptacji zaistniałej sytuacji i poczucia bezradności podczas wykonywania podstawowych czynności.

Upośledzenie niedowidzących związane jest z problemami w uzyskiwaniu informacji i utratą łatwości komunikacji poprzez pismo i wykorzystanie informacji graficznych. Ponadto, niezdolność do odbierania gestów, mimiki, języka ciała, sprawia, że trudno odczytać emocje i informacje generowane przez inne osoby.

Utrata wzroku na stałe lub czasowo, ogranicza lub uniemożliwia życie codzienne, pełnienie roli społecznych i normalne funkcjonowanie w środowisku społecznym. 


\section{Dostępność budynków dla osób z ograniczeniami wzroku}

Dostępność budynków dla osób niepełnosprawnych wzrokowo oraz przystosowanie ich do potrzeb tej grupy użytkowników wiąże się z koniecznością likwidacji barier budowlanych, technologicznych i mentalnych. Na udogodnienia i dostosowania, które ułatwiają korzystanie z budynków i ich sąsiedztwa składają się różne elementy. Mogą one służyć również osobom posiadającym różne czasowe niesprawności, rodzicom z małymi dziećmi oraz osobom starszym. Ze względu na powyższe wymagania konieczne jest oprócz stosowania zasad projektowania bez barier, zastosowanie również zasad projektowania uniwersalnego dotyczącego obiektów użyteczności publicznej. Obiekty użyteczności publicznej definiuje Rozporządzenie Ministra Infrastruktury z dnia 12 kwietnia 2002 roku w sprawie warunków technicznych, jakim powinny odpowiadać budynki i ich usytuowanie (Dz. U. z 2002 roku, nr 75, poz. 690, z p. zm.) . Jest to „budynek przeznaczony na potrzeby administracji publicznej, wymiaru sprawiedliwości, kultury, kultu religijnego, oświaty, szkolnictwa wyższego, nauki, wychowania, opieki zdrowotnej, społecznej lub socjalnej, obsługi bankowej, handlu, gastronomii usług, w tym usług pocztowych lub telekomunikacyjnych, turystyki, sportu, obsługi pasażerów w transporcie kolejowym, drogowym, lotniczym, morskim lub wodnym śródlądowym oraz inny budynek przeznaczony do wykonywania podobnych funkcji; za budynek użyteczności publicznej uznaje się także budynek biurowy i socjalny" [1]. Jak więc widzimy grupa tych obiektów jest bardzo szeroka i niesie za sobą szerokie spektrum funkcji i zagadnien.

Kwestię dostosowania budowlanych obiektów reguluje ustawa z dnia 7 lipca 1994 roku - Prawo Budowlane (Dz. U. z 2006 roku, Nr 156, poz. 1118, z p. zm., t. j. Dz. U. z dnia 23 grudnia 2010 r. Nr 243, poz. 1623. Stan prawny na dzień 29.03.2011). Prawo budowlane określa, że „obiekt budowlany należy projektować i budować w sposób zapewniający (...) m.in. niezbędne warunki do korzystania z obiektów użyteczności publicznej i mieszkaniowego budownictwa wielorodzinnego przez osoby niepełnosprawne, w szczególności poruszające się na wózkach inwalidzkich" [2]. Zapis ten ma za zadanie umożliwić lub w znacznym stopniu ułatwić osobie niepełnosprawnej wykonywanie podstawowych, codziennych czynności lub kontaktów z otoczeniem. Obie definicje są elementami przyjętego i stosowanego od lat systemu projektowanie bez barier.

Bariery budowlane dotyczą utrudnień występujących w budynkach lub ich bliskim otoczeniu, które w związku z rozwiązaniami technicznymi lub warunkami użytkowania znacznie utrudniają swobodę poruszania się osobom niepełnosprawnym również z ograniczeniami wzroku. Bariery techniczne stanowią przeszkody wynikające ze złego zastosowania lub niedostosowania odpowiednich urządzeń do różnego rodzaju niepełnosprawności. Poważne zagadnienie stanowią udogodnienia dla osób niewidomych i niedowidzących. Bariery te utrudniają lub uniemożliwiają osobie swobodne poruszanie się. Likwidacją tego typu bariery jest montaż urządzeń rekompensujących zaburzone funkcje wzroku. 
Dostępność oznacza, że osoby z zaburzeniami funkcji wzroku muszą mieć zapewniony dostęp na równych prawach $\mathrm{z}$ innymi, do transportu wewnętrznego, środowiska fizycznego budynków oraz systemów informacyjnych. Jest to główny warunek do umożliwienia uczestniczenia w każdej sferze życia społecznego i gospodarczego dla osób z zaburzaniem funkcji wzroku. Przestrzeń zbudowana powinna być projektowana $\mathrm{z}$ myślą o potrzebach osób w różnym wieku z różnymi możliwościami motorycznymi i poznawczymi, posiadającymi różne doświadczenie i uwarunkowania kulturowe. Tak pojmowane projektowanie powinno mieć charakter uniwersalny. Takie projektowanie powinno ograniczać wykluczenie społeczne i powinno przynosić rozwiązania projektowe, które umożliwiają dostęp wszystkim bez konieczności wprowadzania modyfikacji specjalnie dla osób niepełnosprawnych w tym osób z zaburzeniem funkcji wzroku. Stworzenie budynków i ich otoczenia bez barier wymaga przemyślanych działań i stosowania filozofii projektowania uniwersalnego w przestrzeni zbudowanej.

\section{Diagnozowanie barier funkcjonalnych i budowlanych - dla osób z ograniczeniami wzroku}

Z uwagi na rożne rozumienie i postrzeganie definicji dostępności, badane zagadnienie wymaga dalszych analiz. Dostępność budynków nie może być oderwana od dostępności jego otoczenia. „Europejska Strategia w sprawie niepełnosprawności 2010-2020”: prezentuje wytyczne budowania „Europy bez barier”, w których jako pierwszy i podstawowy obszar działania wszystkich zaangażowanych podmiotów wskazano dostępność.

„Dostępność” oznacza, że osoby niepełnosprawne muszą mieć zapewniony dostęp do środowiska fizycznego obiektu na równych prawach z innymi.

Istniejące budynki użyteczności publicznej oferują ograniczone możliwości korzystania z nich, powodem jest na przykład umiejscowienie różnych części tej samej instytucji na piętrach i np. braku wind, co utrudnia osobom z dysfunkcjami narządu ruchu i wzroku dostanie się do danej placówki. Niektóre z dostosowań np.: pochylnie lub drzwi wejściowe mają niewłaściwe wyposażenie lub wymiary. Wnętrza budynków wymagają dostosowania i wykonania wielu dodatkowych prac modernizacyjnych, tak by mogły z nich korzystać osoby z ograniczeniami ruchowymi i w widzeniu.

Kluczowym problemem, od którego należy rozpocząc działania zmierzające do usprawnienia dostępności przestrzeni publicznej w budynkach użyteczności publicznej jest zmiana świadomości osób decyzyjnych oraz innych uczestników życia społecznego poprzez zapoznawanie ich z ideą i zasadami projektowania uniwersalnego.

W grudniu 2006 roku na posiedzeniu plenarnym ONZ przyjęła konwencję o prawach osób niepełnosprawnych. Weszła ona w życie 3 maja 2008 roku. Polska podpisała tę konwencję w marcu 2007 roku. Konwencja nakazuje tworzenie warunków do korzystania z praw przez osoby niepełnosprawne na równi z innymi osobami i zakazuje dyskryminacji niepełnosprawnych. Państwa sygnatariusze konwencji zobowiązały się między innymi do opracowania i wdrożenia minimal- 
nych standardów w zakresie dostępności urządzeń i usług ogólnie dostępnych, a także oznakowania w budynkach ogólnodostępnych w alfabecie Braille'a oraz w innych formach łatwych do czytania i zrozumienia.

Według definicji opracowanej przez Center of Uniwersal Design Uniwersytetu Północnej Karoliny w Stanach Zjednoczonych; Projektowanie uniwersalne dla wszystkich, to projektowanie środowiska i innych produktów, które mogą być używane przez wszystkich ludzi, bez potrzeby adaptacji lub specjalistycznego projektowania. Projektowanie to powinno być oparte o odpowiednie zasady. Obiekt powinien być elastyczny i wygodny w użytkowaniu. Powinien posiadać intuicyjne i proste rozwiązania oraz prostą i czytelną informację. Powinien charakteryzować się tolerancją na potencjalne błędy użytkownika. Powinien być użyteczny dla osób o zróżnicowanej sprawności za sprawą odpowiednio dobranych parametrów wielkości i przestrzeni dla prawidłowego dostępu i użytkowania.

Otoczenie zabudowane człowieka powinno być projektowane z myślą o osobach w różnym wieku, mających różny stopień sprawności motorycznej i poznawczej, zróżnicowane doświadczenia i żyjących w odmiennych obszarach kulturowych. Projektowanie uniwersalne dla wszystkich, koncentruje się na szeroko rozumianej różnorodności ludzi i w tym sensie ma uniwersalny charakter wpływający na to, że nikt nie podlega wykluczeniu, a korzyść odnosi każdy użytkownik przestrzeni publicznej. Identyfikacja potrzeb tak zwanych ekstremalnych użytkowników- na przykład osób cierpiących na choroby złożone - którzy nie byli uwzględniani w modelach analitycznych projektowania, pozwoliła poprawić jakość obiektów użyteczności publicznej oferowanych całemu społeczeństwu [3]. Projektowanie uniwersalne zmniejsza stopień stygmatyzacji osób niepełnosprawnych, oferując obiekty niewymagające dodatkowej modyfikacji czy specjalnych rozwiązań funkcjonalnych.

\section{Wnioski}

W przeszłości, w świetle założeń modeli analitycznych, niepełnosprawnych traktowano jako ludzi odbiegających od normy. Przeznaczone dla nich projekty były specjalnymi modyfikacjami rozwiązań pierwotnie opracowanych dla osób sprawnych.

Kolejnym etapem rozwoju metod projektowania w dziedzinie dostępności obiektów użyteczności publicznej dla niepełnosprawnych było tzw. projektowanie bez barier, które znalazło odzwierciedlenie w przepisach polskiego prawa budowlanego i w warunkach technicznych dotyczących obiektów użyteczności publicznej. Obecnie po przyjęciu konwencji ONZ dotyczącej osób niepełnosprawnych zmianie ulega również podejście do zasad projektowania, które powinny spełniać wymogi tzw. projektowania uniwersalnego lub inaczej projektowania dla wszystkich.

Istotą projektowania uniwersalnego jest stworzenie odpowiednich warunków dostępności, przestrzeni publicznej dla osób, które w różny sposób się przemieszczają, z różną precyzją postrzegają otoczenie i w różnym tempie realizują codzienne działania [3]. 
Występowanie różnych schorzeń, rodzajów niepełnosprawności, różnorodnych możliwości motorycznych i ograniczeń psychofizycznych, dzieli osoby niepełnosprawne na grupy sprawności. Wynika z tego, że nie ma jednego, uniwersalnego dla wszystkich sposobu dostosowania budynku do potrzeby osób niepełnosprawnych. Istnieją wytyczne, których zadaniem jest uśrednienie potrzeb osób niepełnosprawnych i umożliwienie, jak największej liczbie takich osób, swobodnego korzystania z budynków. Wytyczne te znajdują się w ustawie z dnia 7 lipca 1994 r. Prawo Budowlane. Konieczne są dalsza praca nad rozszerzeniem katalogu tych wymagań obejmującym nie tylko zakres budowlany ale również zagadnienia $\mathrm{z}$ zakresu projektowania wyposażenia wnętrz w budynkach.

$\mathrm{W}$ związku $\mathrm{z}$ powyższym konieczne jest wprowadzenie zmian $\mathrm{w}$ polskim prawie budowlanym. W ostatnim czasie mieliśmy do czynienia z szeregiem dość istotnych zmian $\mathrm{w}$ prawie budowlanym przy czym w szczególności odnoszą się one do regulacji w zakresie formalnym, a rzadziej w zakresie merytorycznym. Celem takich zmian powinno być rozszerzenie pojęcia niepełnosprawności ograniczające się obecnie do osób poruszających się na wózkach inwalidzkich na inne grupy ograniczenia. Prace nad takimi zmianami wymagają wykonania odpowiednich badan i ekspertyz. Mogą one być przedmiotem odpowiednich badań naukowych.

\title{
Literatura
}

[1] § 3, pkt. 6 rozporządzenia Ministra Infrastruktury z dnia 12 kwietnia 2002 roku w sprawie warunków technicznych, jakim powinny odpowiadać budynki i ich usytuowanie.

[2] Art. 5, ust 1, pkt. 4 ustawy z dnia 7 lipca 1994 roku - Prawo Budowlane (Dz. U. z 2006 roku, Nr 156, poz. 1118, z p. zm., t. j. Dz. U. z dnia 23 grudnia 2010 r. Nr 243, poz. 1623. Stan prawny na dzień 29.03.2011).

[3] Błaszak M., Przybylski Ł.: Rzeczy są dla ludzi. Niepełnosprawność i idea uniwersalnego projektowania, wyd. Scholer, Warszawa 2010. (http://scholar.com.pl/upload/product_ _files/2113/21_AZOzOS_tom10_.pdf).

\section{ARCHITECTURE END THE AVAILABILITY OF PUBLIC FACILITIES FOR THE VISUALLY IMPAIRED}

\begin{abstract}
S u m m a r y
There is a need to create common and consistent rules that would allow understanding disability as a phenomenon of the system. There are many different definitions of disability. The effects it entails visual dysfunction depends on several factors. Multisensory space combines elements of architecture, art and media. The essence of architectural design and rehabilitation facilities are functional, simple and intuitive to use, with an emphasis on open spaces and objects in such a way that their function was understandable for every user, regardless of experience or an advanced degree of dysfunction.
\end{abstract}

Keywords: Architecture, design, rehabilitation facilities, people with visual impairments

DOI:10.7862/rb.2016.292

Przestano do redakcji: $30.06 .2016 r$.

Przyjęto do druku: 20.12.2016 r. 